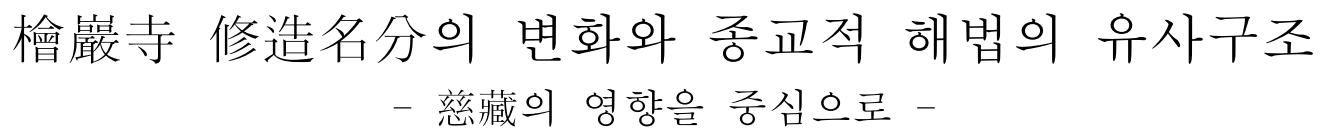

\title{
A Study on the Change of Cause for Rebuilding of Hoeamsa and Analogous Structure of Religious Solution
}

- focusing on Jajang's Influence -

\author{
염 중 섭* \\ Youm, Jung-Seop \\ (동국대학교 철학과 강사)
}

The temple Hoeamsa(檜嚴寺) was repaired by Naong(懶穿), and with this the power of the temple became far greater to be the greatest Buddhist temple during late Goryeo and early Joseon. Naong's reconstruction of Hoeamsa was originated from Jigong(指空)'s teaching 'Samsan Yangsu(三山兩水).' But it is not clear whether Samsan Yangsu really meant Hoeamsa. By the way, after 14 years, Naong suddenly remembered this word and began to repair Hoeamsa in a large scale. From this, we can guess that Naong tried to give the contemporary Buddhism some change through the repair of Hoeamsa.

But, as King Gongmin(恭㥿王) the greatest supporter of Naong was suddenly assassinated, the political situation changed a lot and Naong also died unexpectedly. Naong's death brought out the critical sense to Hoeamsa and, in the process to resolve the crisis, the repair of Hoeamsa began to be justified through diverse religious factors. As these were expanded and developed on and one, Hoeamsa came to be honored as the most divine temple in Korea during the early Joseon dynasty

Furthermore, into the cause structure for the Naong's repair of Hoeamsa, the influence of Jajang was added through Odaesan Buddhism. As we can well understand, late Silla situation of Jajang and the late Goryeo of Naong were very similar and the both Buddhist leaders should have derived out some religious solution for them. In other words, both of them had a similar recognition in finding the religious solution for the contemporary crises. It becomes a way to understand the Hoeamsa repairing structure taken by Naong and his disciples.

Therefore, by comparing the similar religious solution structures given by Jajang and Naong and by clearer understanding on Samsan Yangsu spirit, we can see the repair of Hoeamsa and the related aspects more accurately.

주제어：檜嚴寺, 五臺山, 鐵山紹瓊, 三山兩水, 修造, 指空, 靈骨, 阿蘭陁寺, 懶穿, 恭㥿王

\section{1. 서 론}

懶翁惠勤(1320 1376)은 동시대의 수평적으로는 太古普 愚(1301 1382)·白雲景閑(1298 1374)과 더불어 麗末三師1)

* Corresponding Author : kumarajiva@hanmail.net
로 칭해지는 인물이다. 또 수직적으로는 指空禪賢(1300 1361)·無學自超(1327 1405)와 함께 證明三和合으로 일컬 어진다. 麗末三師와 證明三和尚에 공통으로 위치하는 것이 나옹뿐이라는 점은, 나옹이 얼마나 중요한 의미를 확보하는 인물인지를 잘 나타내준다. 또 나옹에게는 다른 선승들과는 


\section{8 논문}

다른 歌辭文學을 통한 민중불교적인 양상도 존재한다. 이러 한 중요도로 인하여, 나옹과 관련해서는 약 100 여종이나 되 는 학계의 선행연구들이 존재하고 있다.

나옹연구에 대한 중요한 부분은 문학·불교학.사학 쪽에서 의 박사학위논문 4편과,2) 李鍾君3)·전재강4)·李哲憲5)·姜好 鮮6)·金昌淑7)·黃仁奎8)·許興植9)을 필두로 하는 일련의 연구 들이다.10) 그러나 이와 같은 많은 연구들이 존재함에도 불

2）文學-李鍾君，「懶攽和向向 三歌 研究」，釜山大 博士學位論文, 1996 ; 佛敎學-李哲憲, 「懶穿 惠勤의 研究」, 東國大 博士學位論文, 1997 ; 史學一金昌淑(曉呑)，「懶㢦惠勤의 禪思想 研究」，東國大 博士學位論文， 1997 ; 姜好鮮, 「高麗末 頪穿慧勤 研究」, 서울大 博士學位論文, 2011.

3) 李鍾君, 「懶穿 禪詩에 나타난 달(月)의 象徵」, 『韓國文學論叢」 제14집, 1993 ; 「懶穿禪師와 관련된 牧隱의 記文 研究」, 『東洋漢文學 研究」 제9집, 1995 ; 「懶翁和佾의 三歌 研究」, 釜山大 博士學位論文, 1996 ; 「懶穿 三歌의 象徵性 研究」, 『東洋漢文學研究』 제 10 집, 1996 ; 「懶挛三歌의 詩世界」, 『東洋漢文學研究』 제11집, 1997.

4) 전재강, 「懶亝 歌辭에 나타난 詩的 대상 내용과 대상 인물의 성 격」, 『語文學』 제 111 호, 2011 ; 「懶穿 문학의 담화 방식과 갈래 성 격」, 『國語敎育研究』 제48집, 2011 ; 「懶穿 禪詩에 나타난 시공 표 현의 용어 유형」, 『우리말글』 제 57 호, 2012.

5）李哲憲，「懶穿惠勤의 彌陀淨土觀」，『韓國佛敎學』 제 18 호, 1993 「懶穿 惠勤의 法脈」, 『韓國佛教學』 제19집, 1994 ; 「懶翁 惠勤의 樿思想」, 『韓國佛敉學』 제21호, 1996 ; 「懶穿 惠勤의 研究」, 東國大 博士學位論文, 1997 ; 「三和佮法系手 成立斗 流行」, 『韓國佛敎學」 제25집, 1999 ; 「懶穿 惠勤의 民衆 教化」, 『佛教文化研究」, 제9집, 2008

6）姜好鮮，「忠烈·忠宣王代 臨濟宗 수용과 高麗佛敉의 變化」, 『韓國 史論』 제46집, 2001 ; 「高麗末 懶翁惠勤 研究」, 서울대 博士學位論文, 2011 ; 「高麗末 禪僧의 入元遊歷과 元 清規의 수용」, 『韓國思想史 學』 제 40집, 2012

7）金昌淑(曉呑)，「懶穿蟬의 淨土融攝考」，『東院論集』 제10집, 1997

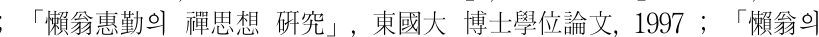
教·戒·密 融攝考」, 『歷史와 教育」 제6집, 1998 ; 「懶穿惠勤의 佛敎史 的位置」, 『寺刹造景研究』 제8권, 2001.

8）黃仁奎,「櫴翁惠勤과 대표적 繼承者 無學自超-懶穿惠勤과 無學自超 의 遭遇事實을 중심으로」, 『東國歷史教育』 제5집, 1997 ; 「懶穿惠勤 의 불교계 行蹟과 遺物·遺蹟-諸 紀錄 및 자료의 검토 試放」, 『大覺思 想』 제11집, 2008 ; 「麗末鮮初 懶穿門徒의 五臺山 中興佛事」, 『佛教 研究』 제36집, 2012.

9）許興植，「懶翁의 思想과 繼承者(上)」，『韓國學報』 제 16 권, 1990 ; 「懶翁의 思想과 繼承者(下)」，『韓國學報』 제16권，1990； 『高麗로 옮긴 印度의 등불』, 一朝閣, 1987.

10) 이 외에 주목되는 것으로는 『三大和向 研究 論文集』이 총 3 권으 로 발행된 것이 있다. 『三大和尙 研究 論文集』 총 3 권에 수록된 논문 들 중 懶翁과 관련된 연구들은 11 편인데, 이를 제시해 보면 다음과 같 다.

불경서당 훈문회 編, 『三大和少 研究 論文集-指空·懶穿·無學和台』, 佛

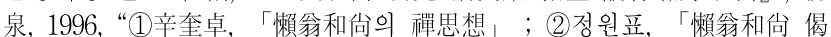
頌의 문학적 성격」; (3)李鍾君, 「懶翁和晌 三歌의 형성 배경 연구」; (4)정상홍, 「懶穿禪師의 ‘三歌詩”형태에 대한 一考」; (5)한성자, 「禪佛 敎와 西洋思想의 주요개념 비교」; (6)김치온, 「懶穿惠勤의 塔銘에 관 한 고찰」”

불경서당 훈문회 編, 『三大和佾 研究 論文集 II-指空.懶穿·無學和佾』, 佛泉, 1999, “(1)박재금, 「懶穿 禪詩의 한 특성」 ; (2)정진원, 「懶穿和 佾 '偈頌'에 대한 텍스트 언어학적 분석(1)」 ; (3)이덕진, 「懶穿惠勤의 緣起說 研究」”

불경서당 훈문회 編, 『三大和向 研究 論文集III-指空·懶穿·無學·涵虛和
구하고, 나옹의 회암사 修造명분 및 이의 대두이유에 관해 서는 이제까지 크게 이렇다할 연구가 진행되지 못하였다. 이는 종래의 회암사와 관련된 연구가, 회암사의 수조의미보 다는 寺址 및 浮圖에 대한 것이 중심을 이루었기 때문이 다.11) 회암사의 수조명분과 관련된 연구는, 許興植이『高 麗로 옮긴 印度의 등불』, 「第3章 檜㦑寺」에서 다루고 있는 일부가 유일하다.12)

회암사의 수조(1374년, 恭㟲王 23 , 禑王 元年)는 功夫選 의 主盟과 王師임명을 통해서 상징적인 國師가 되는 보우 를 제치고 실질적인 고려불교의 1 인자가 되는 나옹이, 새로 운 불교재편의 이상을 제시하고 있다는 점에서 주목된다. 또 회암사의 수조과정에서 나옹이 탄핵을 받아 마침내 의문 의 열반에 이르고 만다는 점에서, 회암사의 수조는 나옹에 대한 정당한 이해정립을 위해서도 매우 중요한 의미를 확보 한다.

본고는 젶장을 통해서 회암사 수조배경으로서의 三山 兩水之記를 검토하고, 이의 의미가 확대되는 양상에 대해서 검토해 보고자 하였다. 이를 통해서 우리는 나옹의 회암사 수조 당위성 및 나옹의 열반과 관련된 문도들의 위기의식을 읽어볼 수가 있게 된다.

또 제피장을 통해서는, 나옹의 회암사 수조에서 확인되는 일련의 구조들이 자장의 문제의식 및 해법과 상호 유사하다 는 점에 대해서 밝혀 보았다. 이는 나옹이 2차례나 주석하 는 오대산불교의 영향이자, 신라 말이라는 위기의 시대를 산 자장과 고려 말 변화기의 나옹이 상호 유사한 관점에서 의 해법도출을 시도한 것으로 판단해 볼 수 있는 부분이다. 또 이를 통해서 우리는 나옹이 오대산불교에 영향을 받고 있는 측면에 관한 한 단면을 인지해 보게 된다.

회암사는 여말선초 불교의 최대 핵심사찰이다. 그러므로 이에 대한 보다 분명한 이해는, 나옹과 그 문도 및 여말선

佾』, 佛泉, 2001, “(1)주호찬, 「懶穿惠勤 悟道詩의 一考察」; (2)이창구, 「懶翁禪의 實踐體系」”

이상의 연구들 말고 다른 것들을 세세하게 나열하는 것은 너무 번거롭 다. 그러므로 懶䓫과 관련된 博士學位論文의 參考文獻 등을 살피는 것 이 타당하다고 판단된다.

11) 檜㦑寺와 관련된 선행연구들을 정리하면 다음과 같다.

최완수, 「檜㦑寺址 舍利塔의 建立緣起」, 『美術史學犐究』, 통권 87 호, 1967 ; 최성봉, 「檜耑寺의 沿革과 그 寺址調査 : 伽藍配置를 中心으 로」, 『佛敎學報』 제9집, 1972 ; 許興植 著, 「第3章 檜踇寺」, 『高麗 로 옮긴 印度의 등불』, 一潮閣, 1997 ; 金潤坤, 「懶穿 惠勤의 檜㟶寺 중창과 反佛論의 제압기도」, 『大邱史學』 제62집, 2001 ; 京畿道博物 館 編, 『묻혀 있던 朝鮮 最大의 王室寺刹 檜品寺』, 京畿道博物館, 2003 ; 嚴基构, 「檜嚴寺址의 石造浮屠와 塔碑에 대한 고찰」, 『文化史 學』 제21호, 2004 ; 한지만·이상해, 「檜巖寺의 沿革과 政廳·方丈址에 관한 復元的 研究」, 『建築歷史研究』 제61호, 2008 ; 한지만, 「檜巖寺 址 日字形 건물지에 관한 연구」, 『建築歷史研究』 통권69호, 2010.

12）許興植 著,「第3章 檜嚴寺」, 『高麗로 옮긴 印度의 등불』, 1997, 一潮閣, 194 245丝. 
초 불교를 이해하는데 있어서 매우 타당한 연구의의를 확보 한다고 하겠다.

\section{2. 회암사 修造배경과 三山兩水之記}

\section{2-1. 지공의 授記와 나옹의 수조배경}

懶穿惠勤(1320 1376)은 20세 때인 1339년(忠肅王 後8) 四佛山 大乘寺에 속한 妙寂菴의 了然 門下로 출가한다.13) 이후 제방을 유력하다가 1344년(忠惠王 4) 양주 회암사에 도착한 뒤, 4년간의 長坐不臥 수행 끝에 25세가 되는 1347 년(忠穆王 3 ) 마침내 悟道하게 된다. 깨달은 직후에 나옹은 곧장 入元 認可遊學을 떠나, 指空樿賢(1300 1361)이 머물 던 大都 法源寺에 入房한다.14) 이후로 나옹은 만 10년이라 는 장기간의 입원생활을 보내게 된다.

이 과정에서 1350년(忠定王 2) 8월 江南 五山佛敎 淨 慈寺의 平山處林 $(1279$ 1361)에게 臨濟法脈을 받고,15) 3년 뒤인 1353년(恭壂王 2)에는 法源寺에서16) 지공의 인가를 증득한다.17) 그리고 1358년(공민왕 7) 3월 13일 지공과 마 지막으로 작별할 때, 지공으로부터 소위 '三山兩水之記'를 받게 된다. 三山兩水之記는 회암사의 수조와 관련해서 매우 중요한 부분이므로, 이의 해당 부분을 적시해 보면 다음과 같다.

\section{정유년(1357년, 공민왕 6)에 (광제선)사에서 물러나 燕}

13）『懶穿和少語錄』，「懶攽行狀」（『韓佛全6」，703a）；〈懶穿碑文> (『韓佛全6」, 710b).

14）같은 책, 「懶穿行狀」(『韓佛全 $6 」, 703 a \cdot b)$ ； <懶穿碑文 $>$ (『韓佛 全6』, 710b)

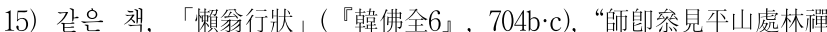
師 山適在僧堂 師直入堂內 東西信步 山云大德從何方來 師云大都來 山云 篔見甚麼人來 答云筸見西天指空來 山云指空日用何事 答云指空日用千劍 山云指空千劍且置 將汝一劍來 師以座具打山 山倒在禪床大叫云 這賊殺我 師便扶起云 吾劍能殺人 亦能活人 山呵呵大笑 師把手歸方丈 請茶留數月 一日手書囑云三韓慧首座 來見老箇 看其出言吐氣 便與佛租相合 宗眼眀白 見處高峻 言中有響 句句藏鋒 茲以雪菴所傳及菴先師法衣一領 拂子一枝 付啒表信”; <懶翁碑文 $>($ 『韓佛全6」，710b)，“是春南遊江淛 秋八月 厽 平山 山問僧見何人 日西天指空 日用千劍 山云且置指空千劍 將汝一劍來 師以坐具(第一六張)提山 山倒在禪床 大呌賊繁我 師日吾劍也 能殺人能活 人 乃扶起 山以雪嚴所傳及笶衣拂子 表信”

16) 大府大監 察肎帖木兒(察军帖木兒, 즉 찰한티물은 百人勇士라는 의미 로 위그르인이었다.『元史』141, 「列傳-察罕帖木兒」; 李則芬 著, 『元史新講』 4 , 中華書局, p. 27, 1978)의 부인인 高麗人 金氏가 시주한 사찰이다(<楊州檜嚴寺指空樿師浮屠碑〉, “大府大監察罕帖木兒之室金氏。 亦高麗人也。從師出家。買宅澄淸里。闢爲佛宮。迎師居之。師題其額日法 源。”).

17）『懶翁和佾語錄』，「懶翁行狀」(『韓佛全 6 」 $705 \mathrm{~b} \cdot \mathrm{c}$ ), “是歲三月 還到大都法源寺 再㕘指空 空迎入方丈 請茶 遂以法衣一領 拂子一枝 护梵 草信書一紙 付囑云 百陽制茶正安[空方丈名]果 年年不昧一通藥 東西看見 南北然 明宗法王給千劍”; <懶穿碑文>(『韓佛全 $6 」, 710 \mathrm{~b})$, “是歲北還再 牟指空 空授以法衣拂子梵書”
지역의 명산을 유력했다. (그러다가) 도로 법원사로 왔 다. 지공에게 묻기를, "제자는 마땅히 어디로 가야할까 요?” 하였다. 지공이 말했다. “자네가 본국으로 돌아가 三山兩水의 사이를 택해서 거처한다면, 곧 불법이 자연 히 흥할 것이네."18)

무술년(1358년, 공민왕 7) 봄에 지공의 授記를 얻어서 동쪽 (고려로) 돌아왔다. ${ }^{19)}$

지공이 나옹에게 삼산양수의 수기를 주는 일을 「나옹행 장」에서는 1357 년이라고 기록하였지만, 李穡은 <나옹비 문>에서 1358년의 일로 적고 있다. 나옹이 지공을 만나서 이 말을 들은 것은 최후 만남 때의 일이다. 또 이 말이 작 별과 관련된다는 점 및 나옹이 1358년 3월 23일에 지공과 헤어지는 것으로 기록되어 있다는 점을 감안한다면, 1358 년 으로 기록하고 있는 <나옹비문>의 기록이 더 타당하고 판 단된다. <나옹비문>의 기술방식상 이색이 나옹의 문도들에 게 1 차 자료를 받아서 작업했을 것이라는 점을 고려한다면, 이색이 기술과정에서 이 부분을 타당성에 입각해 수정한 것 이 아닌가 판단된다.

여기에서 삼산양수가 가리키는 곳이 후일 나옹에 의해서 회암사로 비정된다. 삼산양수에서의 '삼산'과 '양수'가 각각 무엇을 가리키는 것인지는 분명하지 않다. 그러나 회암사와 관련해서 이색은 두 강물이 합류하여 風氣가 저장되고, 뭇 산들은 빙 둘러 있다는 언급을 하고 있어 주목된다.20) 또 이와 관련해 石顛 朴漢英(1870 1948)은 「楊州天寶山遊 記」에서, 삼산은 三角山이고 양수는 臨津江과 漢江으로 비정하고 있다.21) 그의 이와 같은 주장은 오늘날까지도 대 체로 용인되고 있다.22)

그런데 나옹은 귀국 후 곧장 회암사를 찾아서 방법을 강 구하지 않고, 무려 14년이 경과한 1372년(공민왕 21)에야 비로소 지공의 수기를 떠올려 회암사의 修造를 결심하고 있어 주목된다. 이와 관련된 내용을 적시해 보면 다음과 같 다.

18）같은 책,「懶翁行狀」(『韓佛全6」, 706a), “丁西退院 遊燕薊名山 還到法源寺 問指空云 弟子當往何處 空云汝還本國 擇三山兩水間居之 則 佛法自然興矣”

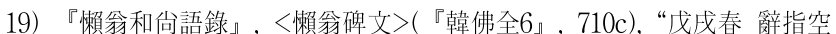
得授記東還”

20）李穡 撰，『牧䧔文菜』20, “同門合坐 錢曹五宰權左使 相視檜䉷山水”

21）石顛寺門(朴漢英）撰，「楊州天寶山遊記」，『朝鮮佛教總報』13，三 十本山聯合事務所, 參照, 1918

22) 許興植 著,「第3章 檜嚴寺」, 『高麗至 옮긴 印度의 등불』, 一潮 閣, 200驽, 1997. 
(1) 임자년(1372년, 공민왕 21) 가을에, 스승은 우연히 지 공의 '三山兩水之記'를 생각하고는 회암사로 옮겨서 주 석할 수 있도록 (上께) 청하였다.

‥云云 $\cdots$

갑인년(1374년, 공민왕 23) 봄에, 또 近臣 尹東明을 보내 어 그 절(회암사)에 주석하기를 청하였다. 스승이 말했 다. "이곳은 내가 처음으로 道에 들어간 곳이요, 또 先 師(지공)의 靈骨을 봉안한 땅이다. 게다가 先師께서 일 찍이 내게 授記하신 (장소)이니, 어떻게 무심할 수 있겠 는가!” 하였다.23)

(2) 임자년(1372) 가을에, 우연히 지공의 '三山兩水之記' 를 생각하고는 회암사로 옮겨서 주석하기를 바랐다. 마 침 (공민왕의) 부름을 받고 이 절의 법회에 나아갔다가 청하여 거처하게 되었다. 스승은 '先師 지공이 일찍이 직접 (이 절을) 重營하였는데, 병란에 燒失되어 버렸으 니 어찌 감히 그 뜻을 잇지 않으리오!' 하고는, 이에 대 중과 모의하여 전각들을 넓혀서 확장하였다.24)

지공의 수기를 귀국 후 14 년 뒤에야 떠올린다는 것도 특 기할만한데, 그것도 두 자료 모두에 공통되게 '우연히(偶)'라 는 말이 들어가 있어 이색적이다. 나옹은 이 수기를 떠올리 기 전해인 1371년(공민왕 20) 8월 26일에 王師에 책봉되고, 그 직후에는 왕명에 의해서 東方第一道場 松廣寺에 주석하 게 된다.25) 또 전해인 1370년(공민왕 19) 9월 16일에는, 淸 平寺에서 功夫選의 主盟으로 고려불교계의 실질적인 1 인자 로서 확실한 두각을 나타낸다.26) 즉 나옹이 삼산양수를 우 연히 떠올릴 때, 나옹은 공부선의 주맹과 왕사 및 사굴산문 수선사계의 대표가 되면서, 실질적인 조계종의 수장이자 고 려불교의 최고인물이 되어 있었던 것이다. 하필 이 무렵에 우연히도 삼산양수지기를 떠올렸다는 것은, 이것이 단순한 지공의 수기에 대한 자각만으로 볼 수 없는 이유가 된다.

23）『懶翁和晌語錄』，「懶翁行狀」(『韓佛全6」，707b)，“壬子秋 師偶 念指空三山兩水之記 請移錫檜踇 …云云 … ㇒甲 寅春又遣近臣尹東明 仍 請住是寺 師日此地是吾初入道處 亦先師安骨之地 沉又先師 會授記於我 鳥得無心哉”

24）같은 책, 〈懶穿碑文>( 『韓佛全6』，709b)，“壬子秋 偶念指空三山兩 水之記 欲移錫檜嘬 會以召赴是寺法會得請居焉 師日先師指空 盖嘗指畫重 營而烑于兵 敢不繼其志 迺謀於衆增廣殿宇”

25）같은 책, 「懶穿行狀」(『韓佛全6』，707b)，“辛亥八月二十六日 遣工 部晌書張子溫 齊書降印护賜金襴袈装內外法服鉢盂. 封爲王師大曹溪宗師禪 教都囱攝勤脩本智重興祖風福國祐世普濟煘者 太后亦獻金襴袈㳖 謂松廣寺 爲東方第一道場”； <懶翁碑文>(『韓佛全6」，709b)，“辛亥八月二十六日 遣工部向書張子溫 齊書降印法服鉢孟皆具 封爲王師大曺溪宗師禪㜞都摠攝 勤脩本智重興祖風福國祐世普濟尊者 謂松廣寺東方第一道場”

26）『高麗史」42，「世家42」，〈恭㷇王5-19年(1370)-9月>，“辛丑：幸廣

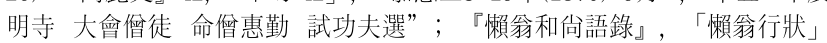

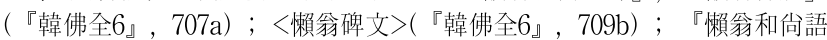
錄』, 「度戊九月十六日國試工夫選場垂語」（「韓佛全』6,722a）；「十七 日垂語」(『韓佛全』6,722b)
특히 나옹은 회암사 修造를 262칸이라는 막대한 규모로 진 행하고 있다.27) 이는 고려 말이라는 혼란의 시대상황에서 볼 때,28) 이 절을 왕사의 下山所로 이해한다고 하더라도 분 명 과도한 측면이 있다.29) 그러므로 우리는 여기에 나옹의 불교개혁과 관련된 구상이 존재한다고 판단해 볼 수가 있게 된다.

위의 인용문 (1)에는 나옹이 회암사의 修造를 결정하는 이유가 총 3 가지로 나타나 있다. 그 첫째는 나옹이 회암사 에서 깨달음을 얻었다는 점. 둘째는 지공의 영골을 모셨다 는 점. 셋째는 지공이 수기한 곳이라는 점이 그것이다. 이 중 첫째와 셋째는 앞서 언급한 바와 같다.

그러므로 둘째에 관해서만 설명하면, 이는 1370 년(공민왕 19) 1 월 1 일에 司徒 達睿가 지공의 영골을 받들어 회암사 에 온 것에서 시작된다.30) 지공은 1361년 11월 29일에 대도 天壽寺31) 歸化方丈에서 열반한다.32) 그러나 당시는 元·明 교체의 혼란기였기 때문에, 이 소식은 6년 후인 1367년 겨 울에야 비로소 普菴에 의해 고려의 나옹에게 전달될 수 있 었다. 이때 보암은 지공이 맡긴 가사와 手書를 전해주었 다.33) 지공의 유해는 團塑肉身 즉 丸彫塑像의 等身佛로 만 들어지게 된다.34) 이는 티베트 라마불교의 영향에 의한 것

27）李穡 撰, 『牧䧔文㩰』2,「天寶山檜嚴寺修造記」, “凡爲屋二百六十 二間。凡佛躬十五尺者七。觀音十尺。”

28) 당시는 倭寇外 飢既의 문제도 있었던 데다가, 특히 魯國大長公主와 관련된 대규모 土木工事, 즉 影殿·正陵·願刹에 대한 恭壂王의 완강한 고 집이 국가적인 문제가 되었다.

강은경, 「高麗後期 辛旽의 改革政治와 理想國家」, 『韓國史學報』 제9

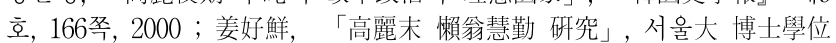
論文, 185 192叒, 2011 ; 崔柄憲, 「牧隱 李穑의 佛敉觀-恭壂王代 政治 改革과 관련하여」, 『牧隱 李穑의 生涯와 思想』, 一朝閣, 175 177쪽, 1996 .

29) 黃仁奎는 檜耑寺가 아닌 松廣寺를 懶永의 下山所 개념으로 이해하 는 다소 특이한 관점을 취하고 있다.

黃仁奎, 「懶翁惠勤의 불교계 行蹟과 遺物·遺蹟-諸 紀錄 및 자료의 검 토 試攻」, 『大覺思想』 제11집, 33쪽, 2008.

30）『懶穿和尙語錄』, 「懶穿行狀」(『韓佛全6」, 707a), “庚戌秋 元朝

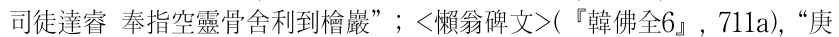
戊春司徒達罕 奉指空靈骨來 厝于檜嵓師禮師骨”

31) 전체적인 문맥상 法源寺 보다는 天壽寺에서 入寂했다고 보는 것이 더 타당하며, 許興植 역시 “天壽寺의 歸化方丈”(『高麗로 옮긴 印度의 등불』, 一潮閣, 115쪽, 1997)으로 보고 있다.

32）〈楊州檜㦑寺指空禪師浮屠碑〉, “天壽寺。吾影堂也。是歲十一月二十 日。示寂于貴化方丈。師所構而師所名也。”

<懶翁碑文>의 20 일은 許興植의 說(「第1章 指空禪賢」, 『高麗로 옮긴 印度의 등불』, 一潮閣, 64쪽, 1997)을 수용하여 본문에서는 29일로 하였 음.

33 ）『懶穿和少語錄』，「懶穿行狀」(『韓佛全6」, 706c 707a), “是年冬 普兴長老 親受指空遺囑袈洮一領手書一紙 到寺授之 師乃披 拈香普說” ; <懶穿碑文>(『韓佛全6」，711a), “其冬猊寶踇 以指空袈㳖手書 授師曰治 命也” 
으로 판단된다.

1368년은 明太租 朱元璋에 의해 南京에서 明이 건국되 고, 이듬해인 1369 년에는 원의 대도가 함락되는 해이다. ${ }^{35)}$ 이와 같은 원·명교체의 혼란과정에서 지공의 等身佛은 1368 년 가을에 兵臨城으로 옮겨져 다비된다.36) 지공의 등신불을 지키려고 했지만 여의치 않자, 결국 문도들이 다비를 택하 게 된 것이다. 이때 지공 영골은 4 등분 되어, 문도인 達立. 清慧·法明·張祿吉이 나누어 모시게 된다.37)

1369년 지공의 문도인 달예는 달현과 함께 고려로 오면 서, 청혜가 모신 것의 일부까지 가지고 와서, 개경을 거쳐38) 1370년 1월 1일 아침에는 최종목적지인 회암사에 도착한 다.39) 이로써 지공 영골의 $2 / 5$ 가량이 고려로 오게 된 것이 다.40) 이 영골을 3월에 나옹이 예배하고, 9월 26일에는 나 옹의 주관으로 지공의 영골이 회암사의 북쪽 봉우리에 모셔 지게 된다.41) 둘째에서 지공의 사리와 영골을 회암사에 모 셨다는 것은, 바로 이와 같은 내용을 의미하는 것이다.

인용문(2)에는 (1)에서 살펴지는 3가지 이유 이외에도, 지 공이 회암사를 중영했으나 병란에 소실되었다는 내용이 더 있다. 여기에서의 전란은 홍건적의 침입에 의해서 개경이 함락되는 1361년(공민왕 10)의 일을 뜻하는 것으로 판단된 다. 또 나옹에 의해서 회암사가 재건이 아닌 修造되고 있다

34）〈楊州檜嚴寺指空禪師浮屠碑〉, “有旨省院臺百司具儀衛。送弇于天壽 寺。明年。御史太夫圖堅帖木兒，本章伯帖木兒函香謁師。用香田泥布梅桂 水團塑肉身。”

35）中探湜 著, 『東洋史概論』, 三英社, 539 540䂬, 2004.

36）<楊州檜䉷寺指空禪師浮屠碑〉, “戊中秋。兵臨城茶毗”

37) 같은 비문, “四分。達玄, 清慧, 法明, 内正張祿吉。各持而去。”

38) 이때 指空 靈骨의 일부는 王輪寺에 남게 된 것으로 판단된다. 이는 1374년(恭愿王 23)에 王輪寺의 指空 頭骨을 恭㥳王이 佛齒와 함께 頂戴 하고서 王宮으로 移運해 오기 때문이다.

『高麗史」42,「世家42」，〈恭烣王5-19年(1370)-正月>，“甲寅 幸王輪 寺, 觀佛齒及胡僧指空頭骨, 親自頂戴, 遂迎入禁中.”

39) 指空의 靈骨이 고려로 들어온 시기와 관련해서 <懶穿碑文>에는 봄 이라고만 되어 있지만(『韓佛全6」, 711a, “庚戊春 司徒達裔 奉指空靈骨 來”), 「懶翁行狀 에는 1 월 1 일이라고 되어 있어 차이가 있다(『韓佛全 $6 』, 707 a$, “庚戊秋 元朝司徒達㕢奉指空靈骨舍利到檜嚴”). 그러나 『高麗 史」의 甲寅日을 계산해보면, 24 일이 된다. 그러므로 1월 1일로 보는 것 이 맞고, 이를 봄으로 인식했다고 보면 되겠다. 실제로『高麗史』와 같 은 경우, 正月을 春正月로 기록하고 있다. 그러므로 양자의 차이는 충돌 하는 것이 아니며, 1 월 1 일이 타당하다고 판단된다.

40) 達玄·淸慧·法明·張祿吉이 각기 4 등분을 했다고 생각하면, 達玄이 가 진 靈骨과 清慧가 가진 일부가 達䜭에게 전해져 고려로 온 것이니, 대 략 2/5정도가 고려로 왔다는 판단이 가능하다.

<楊州檜踇寺指空福師浮屠碑〉, “其徒達玄航海。司徒達㩚從淸慧得之。俱 東歸田。”

41）『懶穿和晌語錄』，「懶穿行狀」(『韓佛全6」，707b），“九月二十六 日將指空靈骨舍利 安塔于寺之北峯”； <楊州檜嚴寺指空禪師浮屠碑〉, “壬子九月十六日。以王命樹浮屠於檜㦑寺。將入塔灌骨。得舍利若干粒。”
는 점에서, 이때의 소실은 완전소실은 아니었던 것으로 이 해된다.

\section{2-2. 회암사 수조 당위성의 확대}

지공이 회암사를 중영했다는 것은, 㕕宗(泰定帝)의 御香 使로 金剛山에 왔을 때의 일을 다소 과장해서 기술한 것으 로 판단된다.42) 이와 관련된 내용을「天罆山檜嚴寺修造 記」는 다음과 같이 기록하고 있다.

(1) 다만 이 절로 말하자면, 철산이 전에 편액을 썼고, 지공이 뒤에 땅을 측량했던 곳이다. 그 '山水之形이 완 연히 西天笛의 蘭陀之寺와 같다'고 한 것이, 또 지공이 스스로 한 말이다. (그러므로) 그 福地가 됨이 너무나도 분명하다.43)

이와 유사하면서 보다 종합적인 기록은, 1452 년 세조비 貞喜王后에 의해서 13 개월 동안 회암사가 重創된 내역을 적고 있는 金守溫의「檜嚴寺重創記」에서 살펴진다.44)

이를 적시해 보면 다음과 같다.

(2) 옛적 天曆年間(1328 1329)에45) 서천 제납박타(薄伽 納提)존자가 이 절의 터를 보고는, '서천 阿蘭陁寺와 똑 같다.'고 말했다. 또 말하기를, “迦葉佛 때에 이미 大道 場이 되었다.'고 하였다. 이에 줄을 잡고 땅을 측량하여 그 위치를 정하는데, 그때 賢劫 이전의 주춧돌과 섬돌 을 발견했다. 당시에는 임시로 屋宇자리를 덮어서 그 대체적인 것을 알 수 있도록만 했을 뿐이다.

(그런데 그 후에) 玄陵의 王師인 普濟尊者가 지공에게 '三山兩水之記'를 받아 와 드디어 이곳에 와서 거처했 다. 이에 크게 중창코자 하여 (여러 사람들에게 필요한) 棟梁을 나누어주어 분주히 募緣하였다. (그런데) 功이 반에도 미치지 못했는데, 왕사가 서거하였다. 그 문도 윤절간 등이 왕사가 마치지 못한 뜻을 생각하여, 이를 계승해서 그 공적을 마쳤다.46)

42）達牧 撰，「六種佛書後誌」，“親對日角 敷揚正法 仍請往觀金剛山因 受御香東行”; 閔漬 撰, 「佛租傳心西天宗派旨要序」, 『西天百八代祖師 指空和向禪要錄』, “遂達于帝京 親對日角 默傳妙旨 因受御香 名以往觀 金剛山 而出來”; 危素 撰, 「文殊師利最上乘無生戒經序」, 『文殊師利 最上乘無生戒經」，“師日吾不爲是也 因東遊高句驟 禮金剛山㨜起菩薩道 場；許興植，「指空의 遊歷과 定着」，『伽山學報』 제 1 호, 92쪽, 1991.

43）李穡 撰，『牧隱文莕』2,「天寶山檜嚴寺修造記」，“第念是寺。鐵山 書額於前。指空量地於後。其山水之形。宛同西竺蘭陀之寺。又指空之所自 言也。其爲福地。蓋甚明矣。”

44）金守溫 撰，『拭㚭集』2，「檜踇寺重創記」，“成化壬辰春。我太王太 妃殿下。…云云 $\cdots$ 始於其年月日。閱幾十有三朔而告記。”

45) 天曆年間은 1328 년에서 1329 까지이며, 指空이 御香使로 高麗에 머 문 기간은 1326 년 3 월부터 1328 년 9월까지의 총 2 년 7 개월간이다. 이렇 게 놓고 본다면 金守溫이「檜㦑寺重創記」를 기술할 당시의 檜耑寺 측 認識에는, 指空이 1328년 1월에서 9월 사이에 檜㦑寺를 다녀간 것으로 되어 있다는 것을 알 수가 있다. 
(1)과 같은 경우는 나옹의 부도와 비석이 건립된 이후의 기록으로, 「나옹행장」이나<나옹비문>에 비해서 성립시 기가 조금 늦다. 그런데 여기에는 「나옹행장」이나 <나옹 비문>에서는 살펴지지 않는 회암사의 수조 당위성을 강조 하는 논리가, 3 가지 더 첨가되어 있다. 그 첫째는 鐵山紹瓊 이 편액을 남겼다는 점. 둘째는 지공이 회암사지를 측량했 다는 점. 셋째는 산수가 인도의 난타사와 똑같다는 점이 그 것이다. 그리고 이러한 사실들이 공통으로 강조하는 것은, 회암사가 희대의 福地라는 주장이라고 하겠다.

이 중 첫째를 검토하면, 鐵山紹瑁은 조계종에 많은 영 향을 미친 蒙山德異의 제자 혹은 계승자로47) 뱃길로 해서 1304년 7월에 와서 1306년 9월 이후에 떠난 인물이다.48) 즉 1326년에 고려를 찾는 지공보다 약 22년 앞서 고려를 방문했던 것이다.

철산은 고려불교에 대한 몽산불교의 강력한 영향에 의해 서, 후일 圓明國師가 되는 修禪社 冲鑑(1274 1338) 등에 의해서 초청되어 고려로 오게 된다. 고려에서 “釋迦之長子” 로까지 존중되는 극진한 대우를 받다가,49) 금강산의 法起道 場을 참배하고 돌아가는 길에 강화 普門寺의 3 본 대장경 중 許評부부가 봉안한 것을 구하여 大仰山으로 옮겨간다.50) 철산은 고려 체류기간 중 금강산에 가는 도중에 회암사에 들렸을 것으로 추정된다.

(1)에서 이와 같은 철산을 거론한 것은, 회암사의 권위를 강조하기 위한 것이다. 「회암사수조기」는 나옹이 회암사

46）金守溫撰，『拭㚭集』2,「檜嚴寺重創記」，“昔天曆間。西天薄伽納 提尊者。見此寺之基。以爲酷似西天阿蘭陁寺。且曰。迦葉佛時。已爲大道 場。於是。執繩量地。以定其位。時得劫前礎砌。當時暫庇屋宇。以識其叢 而已。有玄陵王師普濟尊者。受指空三山兩水之記。透來居此。乃欲大創。 分授棟樑。奔走募緣。功未及牛。而王師亦逝矣。其徒倫絶㵍等。念王師未 究之志。踵其遺矩。以畢其績。”

47) 許興植은 鐵山紹璯을 蒙山의 제자로 본 반면(「高麗에 남긴 鐵山 瓊의 行跡」, 『韓國學報』 제39호, 126 128쪽, 1985), 姜好鮮은 처음에 는 제자로 보았으나(「『蒙山和晌普說』에 나타난 蒙山의 행적과 高麗 後期 佛教界와의 관계」, 『普照思想」 제19집, 182쪽, 2007) 뒤에는 『補續高箇傳』 권12「鐵山璔禪師傳」(CBETA-77, 458c 459a)에 입 각하여 雪嚴祖欽의 제자이자 蒙山의 계승자로 보고 있다(姜好鮮, 「高

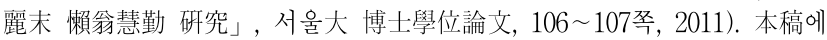
서는 이 문제가 그렇게까지 중요하지 않으므로 두 가지 설을 모두 제시 하는 정도에서 그치고자 한다.

48）許興植, $「 1306$ 년 高麗國大藏移安記」, 『高麗佛敉史研究」, 一潮閣,

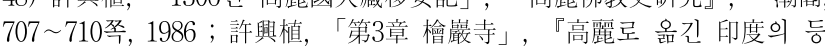
불』, 197쪽.

49）閔漬 撰，「高麗國大藏移安記」，“閨國尊崇 如見佛日 瓶錫所止 四乘 如雲 隨根適器 咸豪茲浲 若非古佛 權現疇克爾耶”.“我和尙雪嵓嫡嗣 亦釋 泇之長子也”

50) 같은 자료, “到江華普門社 見藏經三本問其由來 日二本乃徃古君臣所 安 一是今奉翊大夫知密直司事 軍簿判書上護軍許評 同瑞原郡夫人廉氏了 因所營也 $\cdots$ 云云 $\cdots$ 許公聞之 喜若發蒙 剋日將付歸舟 $\cdots$ 云云 $\cdots$ 因其 言 使斯經轉於斯地”
修造과정에서 臺官(司憲府)과 都堂의 탄핵에 51) 의해서 돌 연히 열반에 이르는 것을 목도한 뒤의 기록이다.52) 그러므 로 회암사의 입장에서는 나옹 이외에도 회암사의 당위성을 세워줄 또 다른 고승이 필요했고, 이 중 임제종 양기파의 몽산 계승자로 고려불교의 신뢰가 두터웠던 철산을 부각시 키는 것으로 판단된다.

그런데 이 기록에서 확인되는 철산과의 인연은 엄밀하게 말하면, 편액 글씨를 받은 정도에 그칠 뿐이다. 이는 당시 회암사의 상황이, 이와 같은 부분마저도 부각해야할 정도로 불투명한 현실 속에 있었다는 것을 말해준다는 점에서 주목 된다.

둘째 지공이 회암사터를 측량했다는 것은, 앞선 <나옹비 문>의 기록에 '지공이 회암사를 중영했으나 소실되었다'는 내용과는 또 다른 것이다. 지공이 인도승려로 고려에서 1326년 3월부터 1328년 9월까지 2년 7개월을 머물기는 했 지만,53) 원래 목적이 금강산 법기도량의 참배였고 수도인 개경에서도 상당기간을 머물렀을 것이라는 점을 감안한다 면,54) 지공의 회암사 중영은 설득력이 떨어진다. 철산과 마 찬가지로 금강산에 가는 도중에 회암사에 들렸고, 이것이 인연이 되어서 修造불사가 이루어진 정도가 아마도 전부일 것이다. 그러므로 회암사를 중영했다는 것은 좀 과장된 내 용이다.

이 같은 점을 고려하여 「회암사수조기」에는, 지공이 회 암사의 대대적인 修造와 관련된 정지작업을 한 것으로만 나타나는 것이 아닌가 한다. 또 나옹이 회암사의 대대적인 修造와 관련되어 탄핵을 당하고 열반한다는 점에서, 나옹의 당위성과 회암사를 보전하기 위해 고려인에게 '붓다와55) 달 마의 再來'로까지56) 숭앙받는 지공에게로까지, 修造의 근원

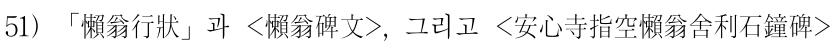
에는 모두 懶翁彈劾의 주체가 “臺(官)”이라고만 언급되어 있다. 그러나 『高麗史」 권133「列傳46」 禑王 2년 丙辰(1376) 4월조에는 “憲府遣 吏, 禁斥婦女, 都堂又令閉關”라고 하여 司憲府와 더불어 都堂이 언급되 어 있다. 姜好鮮은 당시 정국을 都堂이 장악하고 있다는 점을 들어, 탄 핵의 주체를 都堂으로 파악했다(「高麗末 懶翁慧勤 研究」, 서울大 博 士學位論文, 201 204叒, 2011

52) 許興植과 宗梵은 懶攽의 毒殺說을 崔柄憲은 他殺說까지 주장하고 있는 실정이니, 懶翁의 涅槃이 비상식적이고 돌연했던 것만은 분명하다. 許興植，「懶翁의 思想과 繼承者(上)」, 『韓國學報』 제16권, 142쪽, 1990 ; 宗梵, 「懶穿禪風斗 朝鮮佛敉」, 『韓國佛敎文化思想史一伽山李智 冠스님華甲紀念論丵 上』, 伽山佛敉文化研究院, 1147㱙, 1992 ; 崔柄憲, 「牧隱 李穡의 佛教觀」, 『牧隱 李穯의 生涯와 思想」, 一朝閣, 182胥, 1996.

53) 許興植, 「第1章 指空禪賢」, 『高麗로 옮긴 印度의 등불』, 一朝閣, 44 55叒, 1997.

54) 指空의 高麗에서의 遊歷에 대해서는 許興植의「指空의 遊歷과 定 着」,『伽山學報』 제1호, 91 96쪽, 1991에 잘 정리되어 있다.

55）閔漬 撰，「佛租傳心西天宗派旨要序」，『西天百八代租師指空和晌禪 要錄』, “城中士女咸日 釋迦復出 遠來至此 盍往觀乎” 
을 끌어 올리고 있는 것이 아닌가 추정된다. 즉 이 기록은 회암사의 대대적인 修造가 나옹의 판단만이 아닌, 붓다와 달마의 재래인 지공이 먼저 측량한 것을 기준으로 한 것이 므로, 나옹의 개인적인 관점만이 아니라는 점을 변증하고 있는 것이다. 이러한 주장을 통해서, 문도들은 회암사 修造 의 당위성과 나옹의 과도한 修造에 대한 비판을 희석시키 고 있는 것이다.

셋째, 회암사의 산수지세가 인도의 난타사와 같다는 것 역시, 회암사의 당위성과 신성성을 강조하는 주장이다. 회암 사의 '산수지형'을 말하는 것은, '삼산양수'와 관련된 언급이 전부이다. 지공은 나옹에게 삼산양수지기를 주지만, 이는 나 옹이 그곳에 주석하면 고려불교가 발전하기 때문이라는 것 이지, 그곳이 곧 회암사라는 것을 의미하는 것은 아니다. 그 런데 여기에서는 지공의 입을 통해서, 삼산양수를 회암사와 직결시켜 말하고 있다. 또 이와 함께 회암사는 인도의 난타 사와 지세가 같아 기운이 통하는 사찰이라는 주장이 전개되 고 있다.

난타사는 (2)를 통해서도 확인되는 阿蘭陁寺로 인도의 나 란타사(Nālandā-samghārāma, 施無厭寺)를 의미한다. 중국 불교는 한자 ‘阿'자에 특별한 뜻이 없다는 이유로, 음사임에 도 불구하고 阿字를 자주 생략하는 모습이 보인다. 이는 阿 羅漢(arhat)을 羅漢으로 阿彌陀(Amita)를 彌陀로, 그리고 阿蘭若(aranya)를 蘭若로 축약하는 등의 예를 통해서 확인 해 볼 수 있다.57) 물론 이러한 음사에 대한 축약이 '阿'의 원어인 부정사 'a'를 삭제해서, 원뜻을 반대로 왜곡시키는 모습이 나타나기도 한다. 그러나 이러한 중국불교의 특징은 무비판적으로 동아시아불교 전체로 확대되면서, 고려불교 역시 그대로 답습하고 있는 모습을 보인다. 그러므로 여기 에서 난타사를 阿蘭陁寺로, 그리고 이것을 인도의 나란타사 로 이해해도 큰 문제는 없다.

나란타는 지공이 출가하여 수학한 곳이자58) 붓다가 3 개 월 동안 설법한 곳의 대스투파가 존재하는 곳으로,59) 비크

56) 指空의 人相着衣에는 達磨와 유사하다는 부분이 있다(至仁撰, 『澹 居稿」 $1, 「$ 指空和向偈序」, “頗類世之所貌達磨者”) 또 우리나라의 $17 \mathrm{C}$ 眞影 중에 指空을 達磨와 유사한 형상으로 묘사한 眞影도 있어 주목된 다(文明大, 「指空和向 眞影像의 圖像特徵」, 『講座美術史』 제 35 호, 15 18쪽, 2010). 그래서인지 李齊賢의 『益齋亂葟』 권6에는, 당시 고 려 사람들이 스스럼없이 지공을 달마에 비견하는 대목이 살펴진다(『益 齋亂㩰」6,「重修乾洞樿寺記」, “客有問益齋日。昔。梁蕭氏據萬乘之 勢。窮四海之力。造塔立廟。不可勝數。計其功德。豈特百倍河氏一寺而已 哉。而達磨譏之。今指空之於河氏。稱嘆之。此其故何也。 $\cdots$ 云云 $\cdots$ 此 其勢同而理別者耶。至若指空，達磨同別處。待子具一隻眼。却向汝道。”).

57）茲玄 著, 『寺刹의 象徵世界上』, 佛光出版社, 181 182叒, 2012.

58）〈楊州檜䉷寺指空樿師浮屠碑〉, “八歲。備三衣䢪那蘭陁寺講師律賢 所。剃染五戒。”

59）『大唐西域記』9，「摩伽陀國下」(『大正藏』51，923b)，“佛於此處三
라마쉴라(Vikramaśila, 超戒寺)·오단타푸리(Odantapuri, 普 利寺)사원과 더불어 인도불교를 대표하는 최대 사찰이자 대 학이다.60)

인도불교사에서 일반적인 인도불교의 최후는, 1203 년 비 크라마쉴라 사원의 파괴를 잡는다.61) 이는 인도불교에서 비 크라마숼라 사원이 차지하는 위상을 나타내는 것이다. 그러 나 비크라마숼라 사원은 동아시아 전통불교에서는 인지도가 낮다. 이에 비해서 나란타사는 살아서 이미 신화화되기에 이르는 玄牀에 의해서62) 최대의 권위를 가진 사찰로 알려 지게 된다. 바로 이 점이 회암사의 권위를 나란타와 연결시 키는 진정한 이유가 아닌가 한다.

그런데 동아시아불교에서 가장 권위 있는 나란타사가 바 로 회암사와 같다는 것이다. 이는 곧 회암사가 고려불교의 최고-최대의 성지라는 것을 의미한다. 그러므로 이 사찰은 당연히 修造되고 유지되어야 하는 것이며, 나옹은 이러한 당연함을 구현한 인물이라는 주장이 성립된다. 이는 대간과 도당의 탄핵에 대한 회암사 측의 종교적인 변증이라고 하겠 다.

$\ulcorner$ 회암사수조기」를 보다 원형이라고 할 수 있는 「나옹 행장」이나 <나옹비문>과 비교해보면, 우리는 회암사 修造 의 당위성과 聖地주장이 매우 강조되고 있다는 것을 알 수 있다. 이는 나옹이 회암사의 대대적인 修造를 이유로 탄핵 을 받아 열반에 든 것을 강하게 의식한 것으로 판단된다. 즉 우리는 여기에서 나옹문도들의 위기의식을 읽어볼 수가 있는 것이다.

실제로「天寶山檜鋹寺修造記」에는, 나옹의 돌연한 열 반 이후 회암사가 해체될 수 있다는 위기의식이 기록된 부 분이 있어 주목된다.63) 이는 당시의 분위기가 얼마나 험악 했는가를 잘 나타내준다. 또 회암사가 나옹에 의해서 新創 이라고 할 정도의 대대적으로 중창을 거쳤음에도 불구하고, 修造라고 소박하게 표현한 이유를 알 수 있게 해준다. 나옹 의 열반 이후 불어 닥친 회암사의 위기를 극복하기 위해서,

月說法。諸商人等亦證聖果。”; 『大唐大慈恩寺三藏法師傳』3, 「起阿踰 陀國終伊爛拏國」(『大正藏」50,237b), “地本菴沒羅長者園。五百商人以 十億金錢買以施佛。佛於此處三月說法。商人多有證果。”; 玄牀 著, 水谷 眞成 譯, 『大唐西域記』, 平凡社, pp. 295 299, 昭和49.

60）佐夕木敎悟·高崎直道·井八口泰涥·塚本啓祥 著, 權五民 譯, 『印度佛 教史』, 經書院, 118 119·140 141䚷, 1995; 中村元 外 著, 金知見 譯, 『佛陀의 世界』, 김영사, 511 512쪽, 1990 .

61) 호사카 슌지 著, 김호성 譯, 「第2章 印度佛敎 隇亡에 대한 從來의 學說」, 『왜 印度에서 佛敉는 減亡했는가』, 한걸음더, 57 60쪽, 2008 ; 本川彰 著, 『インド佛敉史下卷』, 春秋社, p. 405, 2006.

62) 위안싱페이 著, 장연·김호림 譯, 『中國文明大視野3」, 김영사, 492 493쪽, 2007.

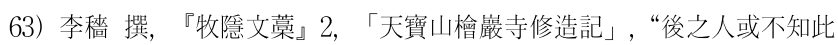
指爲新造撤而去之 則普濟門人 所以劬躬締美之意 滅而不傳” 
회암사 측은 나옹 이외에도 회암사를 보호할 수 있는 방어 기제가 더 요청되었던 것이다. 이것이 바로 '철산'과 '지공', 그리고 '나란타'였던 것이다.

그런데 (2)를 보게 되면, 흥미롭게도 (1)의 회암사 修造 당위성과 성지주장이 보다 진일보되어 확정되고 있다는 것 을 알 수 있다. (2)의 시대는 세조 때이므로, 나옹의 급거와 관련된 위기의식이 작용할 때가 아니다. 그러므로 우리는 처음에는 위기의식에 의해서 회암사의 당위성이 강조되던 것이, (2)에 이르면 위기의식과는 무관하게 이것이 어느덧 정착단계에 이르러 신비화되고 있다는 것을 파악해 보게 된 다.

(2)에서 살펴지는 (1)과의 차이점은, 회암사가 가섭불 때의 사찰터 즉 前佛時代의 절터로 지공이 측량과정에서 그 유 적을 발견했다는 내용이다. 우리는 여기에서 회암사에 대한 당위성과 聖地인식이 마침내 신비화에까지 이르고 있다는 것을 알 수 있다. 전불시대 伽藍址라는 것은, 신라불교에서 살펴지는 최고의 성지개념이다.

또 이러한 전불시대의 성지주장은, 신라를 석가모니의 西 天笈을 능가하는 東天䇥으로까지 만들었다. 이와 같은 내용 을 우리는 『삼국유사』의「阿道基羅」조나64)「朗智乘 雲 普賢樹」65) 哭「皇龍寺丈六」이나66) 「迦葉佛宴坐 石」 조를67) 통해서 확인해 볼 수가 있다.68) 즉 지공의 삼산 양수 수기가 침소봉대되어, 결국 회암사를 전불시대 가람지 로까지 만들고 있는 것이다.

전불시대 가람지라는 것은, 최고의 성지이자 사찰이라는 명예 및 당위성과 관련된 측면이다. 통일신라의 불국사와 같은 경우도 『佛國寺事蹟』에 전불시대 7처가람지에 준하 는 500 禪刹의 첫째라고 기록되어 있을 뿐이다.69) 즉 불국사

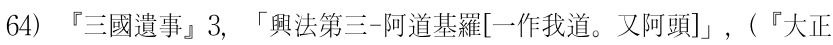
藏」49, 986b), “其京都內有七處伽藍之墟。一日金橋東天鏡林(今興輪寺。 金憍謂西川之憍。俗叱呼云松橋也。寺自我道始基。而中癈。至法興王丁未 草創。乙卯大開。眞興王畢成)。二日三川岐(今永興寺。與與輪開同代)。 三日龍宮南(今皇龍寺。眞興王癸西始開)。四日龍宮北(今芬皇寺。善德甲 午始開)。五日沙川尾(今靈妙寺。善德王乙未始開)。六日神遊林(今天王 寺。文武王己卯開)。七日婿請田(今曇嚴寺)皆前佛時伽藍之墟。法水長流 之地。”

65) 같은 책, 「避䧔第八-朗智乘雲 普賢樹」, (『大正藏』49, 1015c), “靈 熟寺記云。朗智嘗云。此庵址乃迦葉佛時寺基也。”

66) 같은 책, 「興法第三-皇龍寺丈六」, (『大正藏』49, 990a·b), “創東竺 寺。”

67) 같은 책, 「興法第三-迦葉佛宴坐石」, (『大正藏』49, 989a·b).

68) 『三國遺事』에서 前佛時代伽藍址로 나타나는 곳은, 慶州의 7 곳과 蔚山의 靈熟寺로 총8곳이다.

廉仲㷔, $<2$. 慈藏의 개창과 『三國遺事』의 明堂 인식 $>$, 「月精寺의 寺 名에 관한 동양학적인 검토」, 『新羅文化』 제36집, 214 215쪽, 2010.

69）『佛國寺事蹟』全1卷, “其京都內有七處伽藍之墟 $\cdots$ 云云 $\cdots$ 又有五 百樿刹之墟 其第一日妙吉坊今佛國寺”
조차도 전불시대 가람지의 위상에는 미치지 못한 것이다. 그런데 회암사는 고려를 넘어서 조선에 이르러, 마침내 전 불시대 가람지라는 한국불교 최고의 위상을 확보하고 있는 것이다.

\section{3. 회암사 修造의 당위성과 五臺山의 자장}

\section{3-1. 오대산을 통한 자장의 영향}

나옹의 회암사 修造와 관련된 일련의 상황들 속에는, 溟 州의 오대산불교를 통한 자장의 영향이 살펴진다. 이는 나 옹의 회암사 수조목적의 이해와 관련해서 크게 주목되는 부 분이다.

나옹이 첫 번째로 오대산을 찾은 것은 1360년(공민왕 9) 가을로, 원에서 고려로 돌아온 직후의 불확실한 위치 속에 서였다. 그러나 두 번째로 오대산을 찾을 때인 1369년(공민 왕 19) 9 월은,70) 지공의 靈骨이 회암사에 도착하고 나옹이 공부선의 주맹이 되는 1370 년의 전해이다.

이때 나옹은 이미 공민왕 등의 왕실 귀의를 얻고 있었던 상황인데,71) 갑자기 병을 핑계로 오대산 靈感荑(현 五臺山 史庫址임)으로 은거하는 모습을 보인다.72) 나옹은 混修처럼 은거를 선호했던 인물이 아니다.73) 이런 점에서 나옹이 오 대산으로 은거한 것을, 우리는 당시 집권자였던 辛旽과의 충돌로 이해해 볼 수 있다. 왜냐하면 1370년 나옹의 재등장 은 신돈의 급격한 내리막길과 궤적을 같이하며,74) 신돈은 결국 이듬해인 1371년 주살되기 때문이다.75) 또 신돈과 迦 智山門의 普愚 사이에는 강하게 충돌하는 양상도 존재한

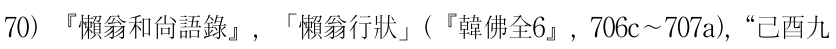
月 以疾辭退 又入臺山 住靈感菴” ; <懶翁碑文 $>($ 『韓佛全 6 』, $710 \mathrm{c})$, “庚 子入臺山居焉”

71) 1361년(恭稂王 10) 10월 15일 恭㹂王의 요청으로 開京으로 들어가 서, 닷새 뒤인 10 월 20 일 원나라 제 11 대 惠宗(順帝)의 願刹인 神光寺의 주지가 된다(『懶穿和向語錄』, 「懶穿行狀」, 『韓佛全6」, 706a；<懶 翁碑文>, 『韓佛全 6 』 $710 \mathrm{c}$ ).

72）『懶翁和向語錄』，「懶翁行狀」（『韓佛全6」，706c 707a), “丁未秋 上命交州道按廉使鄭良生 請住清本寺 $\cdots$ 云云 … 己西九月 以疾辭退 又 入臺山 住靈感菴”； <懶㢦碑文 $>$ ( 『韓佛全6」, 710c), “庚子入臺山居焉”

73）<忠州靑龍寺普覺國師幻庵定慧圓融塔碑> “玄陵高師行誼 請住檜䉷寺 不就 乃入金鼇山 又入五臺山”

74) 1370 년 8월 恭壂王은 親政宣言을 해서 辛旽으로부터 권력을 회수하 고(『高麗史」132, 「列傳45」, <牧逆6-辛旽-013>), 9월 16 17일의 超 㒐科인 功夫選에서 懶翁을 主盟으로 임명한다(『高麗史』42, 「世家4

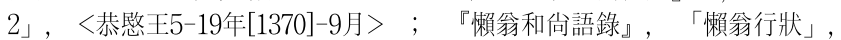
『韓佛全6」, 707a ; 《懶穿碑文>, 『韓佛全6」, 709b). 이후 다음해인 1371년 8월 26일에 懶翁을 王師에 임명하고, 며칠 뒤인 9월에는 東方第 一道場 松廣寺에 주석케 한다(『懶翁和向語錄』, 「懶穿行狀」, 『韓佛 全6』, 707b ; <懶翁碑文〉, 『韓佛全6』, 709b).

75）『高麗史』132, 「列傳45」, <牛逆6-辛旽-015>, “旽當刑束手, 乞哀 於樸日, “願公見阿只, 活我.' 乃斬之, 支解徇諸道, 臬首京城東門.” 
다.76) 이는 나옹과 신돈의 충돌에 대해서도 시사받아 볼 수 있는 한 측면이 될 수 있다.

그런데 오대산에서 나와 1372년부터 회암사를 수조하는 나옹의 명분은, 오대산의 개산조인 자장의 명분론과 구조적 으로 매우 유사한 모습을 모이고 있어 주목된다.

오대산은 자장에 의해서 개착되어 산 전체가 文殊華嚴聖 地가 되는, 우리나라 최초의 성지를 넘어선 聖山이다.77) 또 오대산 불교는 고려시대에 들어서도 태조의 후원을 필두로 하여 성세를 구가하게 된다.78) 이는 현재『삼국유사』에서 가장 많은 기록이 남아 있는 곳이 황룡사와 더불어 오대산 이라는 점을 통해서도 판단해 볼 수가 있다. 더구나 황룡사 와 같은 경우는,「皇龍寺丈六」.「皇龍寺九層塔」.「皇龍 寺鐘 芬皇寺藥師 奉德寺鍾」・「迦葉佛宴坐石」로 황룡사 종이나 가섭불연좌석과 같은 유물까지도 포함한 것이다. 이 렇게 놓고 본다면, 「臺山五萬眞身」.「溟州(古河西府也) 五臺山寶叱徒太子傳記」「「臺山月精寺五類聖衆」「「五臺 山文殊寺石塔記」로 되어 있는 오대산이야말로 『삼국유 사』를 통틀어 가장 큰 영향력을 확보하고 있는 최대의 성 지라고 하겠다.79)

또 오대산과 같은 경우는 나옹이 머물기 1 세대 전쯤, 전 란을 극복하는 과정에서 가람이 일신되는 상당한 규모 이상 의 중수가 이루어졌던 것으로 판단된다. 이는 철산·지공과 도 관련이 있는 민지가, 향전의『오대산사적』을 정리하여 한문으로 바꾸는 과정의 『오대산사적기』 기록을 통해서 인식해 볼 수 있다.80) 특히 『오대산사적기』의 처음에 등

76）『太古和尙語錄』下，「普愚行狀」(『韓佛全6」，699b)，“時辛旽 假 㒐儀 寵幸謟詇 賢良重足 師慨然思危 上書論旽日國之治 眞管得其志 國之 危邪僧逢其時 願上察之遠之 宗社幸甚 $\cdots$ 云云 $\cdots$ 旽用事 䤧于俗離山 師木食 怡然無怨色” ; <太古寺圓證國師塔銘〉, “旽下其事推訊之㟇服 師 之左右錮于俗離寺"

77) 聖山으로서의 金剛山 완성은, 元의 세계관 확대에 의해서 원간섭기 에 이루어지는 것이다.

廉仲紜, 「慈藏의 五臺山 開創과 中臺 寂滅寶宮」, 『韓國佛教學』 제66 호, 16쪽, 2013 ; 許興植, 「指空의 遊歷과 定着」, 『伽山學報』 제 1 호, 92 93空, 1991 ; 金鐸, 「金剛山의 由來와 工 宗教的意味」, 『東洋古 典研究』 제1집, 234 236叒, 1993.

78）『五臺山事跡記』，「信孝居士親見五類聖事蹟」，“我太祖肇開王業依 古聖訓 每歲春秋 各納白米二百石塩五十石別修供養而用資福利 逈以爲歷 代之恒規”

79) 이는 一然의 時代觀 및 佛敉認識과도 관련된 것이다.

廉仲悠、「『三國遺事』五臺山 관련기록의 내용분석과 의미 I 『史 學研究』 제101호, 83叒, 2011 ; 廉仲焂, 「『五臺山事跡記』「第1租師 傳記」의 수정인식 고찰-閔漬의 五臺山佛敉 認識」, 『國學研究』 제 18 집, 241쪽, 2011.

80）『五臺山事跡記』，「信孝居士親見五類聖事蹟의 閔漬跋文部分」， “自經兵火以來國步多艱 供養屢絶 寺亦頽圤已甚 沙門而一見之慨然發嘆兓 已 殫力修莫來謂余日 是山之名 聞於天下 而所有古稽皆羅代鄕言 非四方 君子所可通見 雖欲使人人能究是山寺之靈異 豈可得乎 若他日或有天使 到 山而求觀古記 則其將何以示之哉 願以文易其卿言 使諸觀者 明知大聖靈奇 之跡如日月皎然耳 予聞其言 以爲然 雖自知爲文不能副其意 亦重違其請
장하는 「第一租師傳記」는 오대산의 개창자 자장에 대한 내용이다.81)

자장은 『삼국유사』에서 원효나 의상과 같은 신라의 대 표적인 고승들을 제치고, 가장 많이 등장하는 비조격 인물 이다.82) 이와 같은 측면으로 인하여 자장에 대한 「제 1 조사 전기」는 매우 잘 정리되어 있다. 그렇기 때문에 이는 道宣 의 『續高僧傳』「慈藏傳」과『삼국유사』「慈藏定 律」조의 문제점을 해결해주는 중요한 자료가 된다.83) 즉 이를 통해서 우리는, 나옹 당시 오대산에 개산조인 자장에 대한 이야기가 널리 회자되고 있었다는 것을 알 수 있다. 그도 그럴 것이 당시 자장과 관련된 남쪽의 보궁은 황룡사. 태화사-통도사의 세 곳이나 있었지만, 북쪽 보궁은 오대산 중대가 유일했기 때문이다.84)

물론 당시 고려왕실의 十員殿 좌측 小殿에는, 의상이 발 의해서 도선이 빌려온 제석천이 모셨던 佛牙가, 북송 徽宗 (재위 1100 1125) 때의 도교숭배와 관련해 배척되는 과정 에서 고려로 전래되어 있었다.85) 그러나 이와는 별도로 문 수에게 전해 받은 자장의 불사리 역시, 전통이라는 넘볼 수 없는 권위를 확보하고 있었을 것이다. 그러므로 오대산에 자장에 대한 이야기가 풍미하는 것은 어찌 보면 당연하다.

나옹과 같은 경우는 이러한 오대산불교의 정서를 통해서 보다 구체적으로 자장을 접하게 되었을 것이다. 이러한 과 정에서 자장이 삼국통일 직전의 혼란상을 불교적인 관점으 로 극복하려고 했던 방식에 영향을 받은 것으로 판단된다. 이는 자장과 나옹이라는, '삼국에서 통일신라'와 '고려에서 조선'으로 넘어가는 사회적인 격변기 속의 종교수장이 취할 수 있는 공통된 문제의식과 고민의 결과라고 하겠다. 즉 양 자는 단순 모사가 아닌 비슷한 환경 속에서 파생되는 영향

\section{而筆削云爾”}

81）같은 책, 「奉安舎利開建寺庵第一祖師傳記」; 廉仲篎, 「『五臺山 事跡記』「第1祖師傳記」의 수정인식 고찰-閔漬의 五臺山佛敉 認識」, 『國學研究』 제18집, 參照, 2011 .

82）廉仲临, 「慈藏의 五臺山 開創과 中臺 寂滅寶宮」, 『韓國佛教學」 제66호, 67 68쪽, 2013.

83）廉仲笅,「『五臺山事跡記』「第1租師傳記」의 수정인식 고찰-閔 漬의 五臺山佛敉 認識」, 『國學研究』 제18집, 232 264叒, 2011.

84) 張成在, 「寂減寶宮의 변천과 사상- - 然을 통해 본 5 大寶宮에 대 한 정합적 이해」, 『韓國佛敉學』 제66호, 122 133쪽, 2013.

85）『三國遺事』3，「塔像第四-前後所將舍利」(『韓佛全』6，993b·c), “嘗聞帝釋宮有佛四十齒之一牙。爲我等輩請下人間。爲福如何。律師後與 天使傳其意於上帝。帝限七日送與。湘公致敬記。邀安大內。後至大宋徽宗 朝。崇奉左道。時國人傳圖識日。金人敗國。黃巾之徒諷。日官奏日。金人 者佛敎之謂也。將不利於國家。議將破滅釋氏。坑諸沙門。焚燒經典。而別 造小舡。載佛牙泛於大海。任隨緣流泊。于時適有本朝使者至宋。聞其事。 以天花茸五十領。紵布三百匹。行賂於押舡內史。密授佛牙。但流空舡。使 臣等既得佛牙來奏。於是䜭宗大喜。奉安于十員殿左掖小殿。常錀匙殿門。 施香燈于外。每親幸日開殿曕敬。” 
관계인 것이다.

\section{3-2. 회암사 수조배경의 유사성 정리}

나옹의 회암사 修造에서 시작되는 일련의 내용들은, 자장 의 행적과 구조적으로 매우 흡사한 양상을 보이고 있다. 이 는 크게 '나옹에 의한 것'과, '나옹의 열반 이후 위기의식을 느낀 문도들에 의한 것'의 두 가지로 나누어 볼 수 있다. 그런데 이러한 두 가지의 층차 모두가 전체적으로 자장의 궤적과 일치하고 있어 주목된다. 이는 양자가 주장배경에는 차이가 있지만, 두 가지 모두 나옹에게서 비롯된 자장의 구 조 속에 존재하기 때문으로 판단된다.

이 중 먼저 나옹에 의한 것을 정리해 보면 다음과 같다.

자장은 선덕(여)왕 치세의 위기상황에 따른 우환의식을 가지고 있었다. 이는 문수보살이 자장에게 '여자를 왕으로 삼아서 덕은 있으나 위엄은 없다'고 말하는 내용을 통해서 잘 나타난다. 그리고 이의 대안으로 제시받는 방법이 바로 황룡사에 9 층목탑을 건축하는 것이다.86) 9 층목탑의 건립과 관련해서는, 문수보살이 아닌 終南山 圓香禪師에게 들은 것이라는 기록도 전하고 있다.87)

9층목탑 건립이 중요한 것은, 이 탑이 세워지게 되면 주 변나라들이 모두 항복하게 되기 때문이다.88) 이는 종교를 이용해서 문제를 해결하려는 방식으로, 9 층목탑은 眞興王代 의 皇龍寺丈六尊像과 眞平王의 용으로 만들어진 天賜玉帶 와 더불어 신라의 三寶로까지 확립된다.89) 즉 이를 통해서 우리는, 지금과는 다른 과거의 종교성을 이용한 타당성을 인지해 볼 수가 있게 되는 것이다.90)

86) 廉仲焂, < II. 善德王에 대한 관점 차이>, 「善德王의 轉輪聖王적인 측면 고찰」, 『史學砰究』 제93호, 3 15叒, 2009 ; 『三國遺事』3, 「塔像第四-皇龍寺九曆塔」(『大正藏』49，990c), “經由中國太和池邊。 忽有神人出問。胡爲至此。藏答曰。求菩提故。神人禮拜。又問。汝國有何

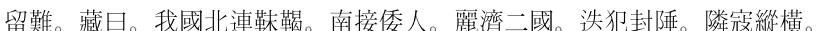
是爲民梗。神人云。今汝國以女爲王。有德而無威。故隣國謀之。宜速歸本 國。藏問歸鄉將何爲利益乎。神日。皇龍寺護法龍。是吾長子。受梵王之 命。來護是寺。歸本國成九層塔於寺中。隣國降伏。九韓來貢。王祚永安 矣。建塔之後設八關會。赦罪人。則外賊不能篇害。更爲我於京畿南岸置一 精盧。共資予福。予亦報之德矣。言已遂奉王而獻之。忽隱不現(寺中記 云。於終南山圓香禪師處。受建塔因由)。”

87)「皇龍寺九層塔刹柱本記 와『寺中記』에 전하는 것으로(黃壽永 編，『新羅金石遺文』，一志社，159叒，1976；金相鉉，「新羅 三寶의 成 立과 그 意味, 『東國史學』 제14호, 60 61쪽, 1980), 太和池 龍과 圓 香禪師의 관계성에 대해서는 李仁哲의 언급( 「芬皇寺 創建의 政治·經濟 的 背景」, 『新羅文化祭學術發表會論文集』 제20호, 17쪽, 1999)이 있 다.

88) 廉仲省,「善德王의 轉輪聖王적인 측면 고찰」, 『史學研究」 제93 호, 36 40쪽, 2009 .

89）『三國遺事』3，「塔像第四-皇龍寺九層塔」(『大正藏』49，991a)， “後高麗王將謀伐羅。乃日。新羅有三寶。不可犯也。何謂也。皇龍丈六。

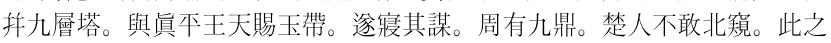
類也。”
그런데 나옹 역시 고려 말 격동기의 시대상황과 배불의 확대로 인한 우환의식을 가지고 있었다. 또 입원해서 지공 에게 삼산양수지기라는 불교가 길이 흥할 방법을 받아오고 있다. 지공은 고려에서 붓다 및 달마의 재래로까지 평가되 는 고승이다. 이런 점에서 이는 자장이 문수 혹은 원향선사 에게 건탑 수기를 받은 것과 구조적으로 유사하다.

나옹은 1372 년 갑자기 지공의 수기를 기억하고 회암사의 修造라는 대규모 토목공사에 돌입한다. 회암사는 이후 여. 말선초에 비견될 수 없는 최대사찰로 자리매김하게 된다.91) 이 역시 백제에서 공장 阿非知를 초청해서야 겨우 완성되 는, 동아시아 최대의 황룡사9층목탑의 건조92) 및 이것이 신 라 삼보로 편입되는 것과 구조적인 유사성이 확보된다.

다음으로는 나옹문도들에 의해서 추가되는 것이 있는데, 이를 정리해 보면 다음의 세 가지로 요약할 수 있다.

첫째는 회암사에 대한 나옹문도의 인식에, 나옹이 삼산양 수지기를 통해서 고려에 두루 이익을 베풀었다는 주장이 살 펴진다는 점이다.93) 이는 자장이 황룡사9층목탑을 건립하여 삼국통일에 기여했다는 인식과 유사하다.

둘째는 황룡사가 중국오대산 태화지 용의 맏아들이 수호 하는 전불시대 가람지로 불리는 곳이자,94) 가섭불이 참선했 던 연좌석이 있던 성지 중의 성지라는 점이다.95) 그런데 회 암사 역시 최고의 성지로 주장되며, 마침내는 가섭불의 전 불시대 가람지로까지 발전하고 있다.

마지막 셋째는, 한국오대산이 개창되는 이유가 중국오대 산의 문수보살이 자장에게 현신하여, 우리나라의 명주지방 에도 중국오대산과 통하는 문수주처가 존재하므로 찾으라고 말한 것에서 시작된다는 점이다.96) 이것이 원인이 되어 귀

90) 이와 같은 양상은 1011년(顯宗 2) 契丹의 침입 때, 大藏經을 발원하 여 佛力으로 물리치는 것을 통해서도 확인된다. 즉 이러한 인식은 中世 의 고려에도 그대로 유전되고 있었던 것이다(李奎報 撰, 『東國李相國 全集』25,「大藏刻板君臣新告文」; 千惠鳳著, 『韓國典籍印刷史』, 沉 友社, 81叒, 2001.

91) 李稛과 같은 경우는 入元 遊學者였다는 점에서, 그의 이 같은 기술 은 당시 檜巖寺의 웅장하고 화려한 모습을 짐작케 한다.

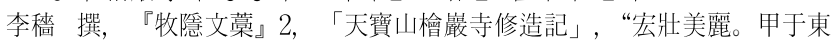
國。遊覽江湖行遍者皆日。雖中國。未之多見。非誇言也。”

92）『三國遺事』3，「塔像第四-皇龍寺九層塔」(『大正藏』49， 990c), “乃以寶帛請於百濟。匠名阿非知。受命而來。”; 「皇龍寺刹柱本紀」, “大匠[百]濟阿[非]等率小匠二百人”

93）李穑 撰，『牧隱文㩰』10, 「仲英說」，；徐居正 外 編，『東文選」 97，「說」, “三山二水之記畢矣。設利遍于東土矣。”

94) 같은 책, 「塔像第四-皇龍寺九層塔」(『大正藏」49,990c), “神曰。 皇龍寺護法龍。是吾長子。受梵王之命。來護是寺。”

95）같은 책, 「興法第三-迦葉佛宴坐石」, (『大正藏』49, 989a·b).

96) 같은 책, 「塔像第四-臺山五萬眞身」(『大正藏」49, 998c), “圣曰。 汝本國艮方溟州界有五臺山。一萬文殊常住在彼。汝往見之。言已不現。” 『五臺山事跡記』, 「奉安舍利開建寺庵第一祖師傳記」, “圣日 卿之本 
국한 자장에 의해서 한국오대산이 개창되고,97) 이후 성산으 로까지 확대·발전하는 것이다. 그런데 이는 회암사가 인도 의 나란타사와 지세가 통한다는 주장과, 이와 같은 당위성 에 의해서 나옹과 문도들에 의해 대가람으로 면모가 일신하 고 있는 것과 구조적인 유사성을 보이고 있다.

이외에도 회암사는 붓다의 후신인 지공의 영골과 사리를 모신 곳이다.98) 이는 자장이 문수에게서 전해 받은 사리를 오대산 중대에 모시고,99) 또 황룡사·통도사-태화사를 통해서 한국불교 사리신앙의 토대를 확보하는 인물이라는 점에서 상호 유사관계가 확보된다. 실제로 지공의 영골은 고려로 전해졌을 때, 공민왕이 직접 머리에 頂戴하고서 이운했을 정도로 존숭 받고 있다.100) 더 흥미로운 것은 이때 붓다의 사리도 함께 이운되고 있다는 점이다.101) 즉 지공의 영골은 붓다의 사리에 필적할 정도의 존숭을 받고 있는 것이다. 이 렇게 놓고 본다면, 나옹이 지공의 영골을 회암사에 모시고 이후 사찰을 修造하는 구조는, 자장의 행적과 매우 유사하 다는 것을 인지해 볼 수가 있다.

나옹은 당시 東京인 경주를 방문한 기록이 없다. 그럼에 도 불구하고 나옹의 행동양식에서 자장과 매우 유사한 구조 가 발견되고 있는 것이다. 이를 우리는 오대산을 통한 자장 의 영향으로 이해해 볼 수가 있다. 즉 오대산을 통한 자장 은, 나옹의 관점정립과 행동양식에 있어서 매우 많은 영향

國溟洲之地 亦有五坮山一萬文殊常住眞身之所也 卿還本國可徃親泰(已上 出臺山本記)”

97）같은 책，「塔像第四-臺山五萬眞身」（『大正藏』49, 998c）；『三國 遺事』3，「塔像第四-臺山月精寺五類聖衆」(『大正藏」49，1000a）； 『五臺山事跡記』, 「奉安舍利開建寺庵第一祖師傳記」。

98) 指空의 門徒가 모시고 온 指空의 遺骸는 솜利가 아닌 靈骨이다. 그 런데 이를 檜巖寺 浮圖를 모셔서 奉安하는 과정에서 懶翁이 靈骨 속에 서 舍利를 발견하게 된다(<楊州檜嚴寺指空禪師浮屠碑〉, “壬子(1372)九 月十六日。以王命樹浮屠於檜巖寺。將入塔灌骨。得舍利若干粒。”). 이를 통해서 우리는 靈骨과 솜에에는 차이가 있다는 것을 알게 된다.

99) 慈藏이 五臺山 中臺에 舍利를 모셨다는 것은(『五臺山事跡記』, 「奉安舍利開建寺庵第一祖師傳記」, “後往溟州(今江陵也)五臺山登地爐峰 奉安佛腦及頂骨 立碑於伽羅墟(碑則䈱而不現)”） 후대에 附加된 내용일

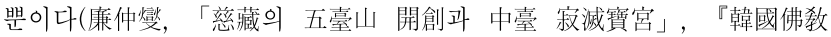
學』 제66호, 29 41쪽, 2013). 그러나 懶穿과 그 門徒들은 이와 같은 부가된 기록을 사실로 믿었을 것이다. 즉 이것은 거짓이지만, 懶㧒과 門 徒들에게는 분명한 사실이었다는 말이다.

100) 1369 년 指空의 門徒인 達睿는 達玄과 함께 高麗로 오면서, 清慧가 모신 것의 일부까지 가지고 와서, 開京을 거쳐 1370 년 1 월 1 일 아침에 는 최종목적지인 檜䰙寺에 도착한다. 이 靈骨을 3 월에 懶穿이 예배하고, 9 월 26일에는 懶翁의 주관으로 指空의 靈骨이 檜嚴寺의 북쪽 봉우리에 모셔지게 된다(『懶永和晌語錄』, 「懶翁行狀」, 『韓佛全6」, 707b, “九 月二十六日 將指空靈骨舍利 安塔于寺之北举” ; <楊州檜嚴寺指空禪師浮 屠碑>, “壬子九月十六日。以王命樹浮屠於檜藂寺。將入塔灌骨。得舍利若 干粒。”). 이 과정에서 指空 靈骨 중 頭骨이 開京 王輪寺에 남게 된 것 으로 판단된다.

101）『高麗史』42，「世家42」，〈恭壂王5-19年(1370)-正月>, “甲寅 幸 王輪寺, 觀佛齒及胡㒐指空頭骨, 親自頂戴, 遂迎入禁中.”
을 주고 있다는 말이다.

이상의 유사구조를 통해서, 우리는 지공이 직접 회암사를 지칭한 것도 아닌 삼산양수지기라는 다소 애매한 말이 회암 사로 확정되고 대대적인 修造로 변화하는 과정에는, 오대산 을 통한 자장의 영향이 존재한다는 것을 인식해 볼 수가 있 다. 즉 나옹은 회암사 수조를 통한 새로운 대안제시와 관련 해서, 자장과 유사한 모종의 해법을 염두에 두고 있었던 것 이다.

\section{4. 結論}

이상을 통해서 우리는 회암사의 수조배경이 되는 삼산양 수지기가 어떻게 확대되면서 회암사가 신성화되는지, 그리 고 이와 같은 과정에 오대산불교를 통한 자장의 존재하는 측면에 관해서 검토해 보았다.

나옹이 산 고려 말은 중세와 근세가 교차하는 격동기였 다. 또 중국에서는 원·명교체기이자 우리나라는 여말선초의 전환기였다. 그리고 사상적으로는 중세의 지배이데올로기인 불교가 신유교 성리학에 점차 밀려나는 상황이었다. 이 외 에도 민족적으로는 몽고족 우위 상황이 한족의 약진과 더불 어, 몽고에 의한 거대한 세계관이 무너지고 있었다. 이러한 거대한 변화 속에 인도적인 지공불교와 같은 부분까지 존재 한다는 점에서, 나옹의 시대는 매우 특징적이고 복잡한 동 시에 많은 문제들을 내포하고 있었다.

이와 같은 시대배경 속에서 공민왕의 후원에 의해 일약 고려불교의 1 인자로 부각하게 되는 나옹에게는, 고려불교를 부흥시켜야만 하는 시대적 요청이 주어져 있었다. 이의 해 결책으로 제시된 유형적인 양상이 바로 회암사의 수조이며, 그 과정에서 명분으로 대두되는 것이 지공의 삼산양수지기 이다. 그러나 공민왕의 돌연한 훙거로 인하여 정국이 급전 환하면서 나옹이 열반하게 되자, 회암사의 수조 당위성 역 시 철산과 지공 및 나란타사와 같은 양상으로까지 확대되게 된다. 또 이와 같은 변화는 결국 조선에 이르러 더욱 신성 화되어, 회암사는 전불시대 가람지라는 한국불교 최고의 위 상을 확보하기에 이른다.

또 나옹의 회암사 수조에 있어서의 명분구조에는, 오대산 불교를 통한 자장의 영향이 살펴진다. 이는 자장이 살던 신 라 말의 상황이 나옹이 처해있던 고려 말과 상호 유사한 측 면에서, 두 사람 모두 불교의 수장으로서 종교적인 해법을 도출해야만 했기 때문으로 이해된다. 즉 종교적인 문제해결 방식에 있어서 양자 사이에는 유사구조가 인식되는 것이다. 이는 나옹과 그 문도들의 회암사 수조구조를 이해하는 한 해법이 된다. 즉 우리는 자장과 나옹간의 종교적인 해법의 
유사구조와 삼산양수지기에 대한 보다 분명한 이해를 통해 서, 회암사 수조와 관련된 측면을 보다 명확하게 조명해 볼 수 있게 되는 것이다.

\section{References}

1.『三國遺事』，『大正藏』49.

2.『大唐大慈恩寺三藏法師傳』，『大正藏』50.

3.『大唐西域記』, 『大正藏』51

4. 『補續高僧傳』, CBETA-77.

5.『懶䓉和尙語錄』，『韓佛全 6 』。

6. 達牧 撰, 「六種佛書後誌」.

7. 閔漬 撰, 「高麗國大藏移安記」.

8. <安心寺指空懶䓉舍利石鐘碑> .

9. <楊州檜嚴寺指空禪師浮屠碑〉.

10. <忠州靑龍寺普覺國師幻庵定慧圓融塔碑>

11.「皇龍寺九層塔刹柱本記」。

12.『高麗史』

13.『佛國寺事蹟』.

14.『五臺山事跡記』。

15.『元史』.

16. 金守溫撰，『拭疮集』.

17. 閔漬 撰, 「佛祖傳心西天宗派旨要序」，『西天百八代 祖師指空和合禪要錄』

18. 徐居正 外 編, 『東文選』.

19，危素 撰，「文殊師利最上乘無生戒經序」，『文殊師利 最上乘無生戒經』.

20．李奎報 撰，『東國李相國全集』．

21. 李穡 撰, 『牧隱文葈』.

22. 李齊賢 撰, 『益齋亂莒』。

23. 至仁 撰，『澹居稿』。

24. 李則芬 著, 『元史新講』4, 中華書局, 1978.

25，玄牀 著，水谷眞成 譯，『大唐西域記』，本凡社，昭和 49 .

26. 石顛沙門(朴漢英) 撰，『朝鮮佛敎總報』13，三十本山 聯合事務所, 1918.

27. 申採湜 著，『東洋史概論』，三英社， 2004.

28. 茲玄 著, 『寺刹의 象徵世界上』, 佛光出版社, 2012.

29. 千惠鳳 著, 『韓國典籍印刷史』, 沉友社, 2001 .

30. 黃壽永 編, 『新羅金石遺文』，一志社， 1976.

31. 위안싱페이 著, 장연·김호림 譯 , 『中國文明大視野 3 3, 김영사, 2007.

32. 佐夕木敎悟·高崎直道·井八口泰淳·塚本啓祥 著，權五民 譯，『印度佛敎史』，經書院，1995。

33. 中村元 外 著, 金知見 譯, 『佛陀의 世界』, 김영사,
1990

34. 호사카 슌지 著, 김호성 譯, 『왜 印度에서 佛呚는 滅 亡했는가』, 한걸음더, 2008.

35. 平川彰 著，『インド佛敎史下卷』，春秋社, 2006.

36. 姜好鮮, 「高麗末 懶穿慧勤 研究」, 서울大 博士學位 論文, 2011.

37. 李仁哲，「芬皇寺 創建의 政治·經濟的 背景」，『新羅 文化祭學術發表會論文集』 제20호, 1999 .

38. 宗梵，「懶翁禪風과 朝鮮佛敎」，『韓國佛教文化思想 史一伽山李智冠스님華甲紀念論叢上』，伽山佛敎文化研 究院, 1992.

39. 崔柄憲 著, 『牧隱 李穑의 生涯와 思想』, 一朝閣, 1996.

40. 許興植 著, 『高麗로 옮긴 印度의 등불』, 一潮閣, 1997.

41. 許興植 著, 『高麗佛教史研究』, 一潮閣, 1986.

42. 강은경, 「高麗後期 辛旽의 改革政治와 理想國家」, 『韓國史學報』 제 9 호, 2000 .

43. 姜好鮮, 「『蒙山和佾普說』에 나타난 蒙山의 행적과 高麗後期 佛敎界와의 관계」, 『普照思想』 제 19 집, 2007.

44. 金相鉉,「新羅 三寶의 成立과 ㄱ 意味」, 『東國史 學』 제 14 호, 1980.

45. 金鐸,「金剛山의 由來와 그 宗教的 意味」, 『東洋古 典硳究』 제1집, 1993

46. 文明大, 「指空和向 眞影像의 圖像特徵」, 『講座美術 史』 제35호, 2010

47. 廉仲燚,「『三國遺事』五臺山 관련기록의 내용분석 과 의미 I」, 『史學䂰究』 제101호, 2011.

48. 廉仲噰, 「善德王의 轉輪聖王적인 측면 고찰」, 『史 學碑究』 제93호, 2009.

49. 廉仲敦, 「『五臺山事跡記』「第1祖師傳記」의 수정 인식 고찰-閔漬의 五臺山佛敎 認識」, 『國學研究』 제 18집, 2011.

50. 廉仲營, 「月精寺의 寺名에 관한 동양학적인 검토」, 『新羅文化』 제36집, 2010.

51. 廉仲焂, 「慈藏의 五臺山 開創과 中臺 寂滅寶宮」, 『韓國佛敎學』 제66호, 2013

52. 張成在, 「寂滅寶宮의 변천과 사상-一然을 통해 본 5 大寶宮에 대한 정합적 이해」, 『韓國佛敎學』 제66 호, 2013.

53. 許興植,「高麗에 남긴 鐵山 瓊의 行跡」, 『韓國學 報』 제39호, 1985.

54. 許興植, 「懶䓉의 思想과 繼承者 $($ 上)」，『韓國學報』 제 16 권, 1990.

55. 許興植，「指空의 遊歷과 定着」, 『伽山學報』 제 1 호, 
1991.

56. 黄仁奎, 「懶翁惠勤의 불교계 行蹟과 遺物·遺蹟-諸 紀 錄 및 자료의 검토 試放」, 『大覺思想』 제 11 집, 2008.

접수(0214. 02. 14)

게재확정(2014. 6. 30) 